\title{
Protective Effects of Flavonoid and Polyphenol from Lotus Leaf on Lung Damage Induced by Inhalation of $\mathrm{N}_{2} \mathrm{O}_{4}$ in mice
}

\author{
Wenjun $\mathrm{Li}^{1,2}$, Ning $\mathrm{Xu}^{1,2}$, Yong $\mathrm{Hu}^{1,2}$, Zhijie $\mathrm{Liu}^{1,2}$, Wei $\mathrm{Li}^{1,2 *}$, Deyuan $\mathrm{Li}^{3 *}$ \\ ${ }^{1}$ Hubei University of Technology, Hubei Key Laboratory of Industrial Microbiology. \\ KeyLaboratory of Fermentation Engineering (Ministry of Education), Wuhan, 430068, China. \\ ${ }^{2}$ National "111" Center for Cellular Regulation and Molecular Pharmaceutics, Hubei Research Center of Food Fermentation Engineering \\ and Technology, Wuhan, 430068, China. \\ ${ }^{3}$ Function Food key Laboratory of Hubei province Hubei Uinversity of Chinese Medicine Wuhan, 430065, China.
}

\begin{abstract}
To study the protective effects of flavonoid and polyphenol (FP) from lotus leaf on the damage induced by $\mathrm{N}_{2} \mathrm{O}_{4}$ in mice. Constructing an animal damage model through exposing mice to $45 \mu \mathrm{N}_{2} \mathrm{O}_{4}$ in a $120 \mathrm{~L}$ sealed cabinet for 30 minutes. ICR male mice were randomly divided into normal group, physiological saline $+\mathrm{N}_{2} \mathrm{O}_{4}$ group, $1.25 \mathrm{~g} / \mathrm{kgFP}+\mathrm{N}_{2} \mathrm{O}_{4}$ group, $2.50 \mathrm{~g} / \mathrm{kgFP}+\mathrm{N}_{2} \mathrm{O}_{4}$ group, $3.75 \mathrm{~g} / \mathrm{kg} \mathrm{FP}+\mathrm{N}_{2} \mathrm{O}_{4}$ group. $1.25,2.50,3.75 \mathrm{~g} / \mathrm{kg}$ FP were orally administered to mice respectively for 5 days, equal volume physiological saline for normal group and physiological saline $+\mathrm{N}_{2} \mathrm{O}_{4}$ group. Then, the three FP groups and the physiological saline $+\mathrm{N}_{2} \mathrm{O}_{4}$ group were exposed to $\mathrm{N}_{2} \mathrm{O}_{4}$ in the cabinet on 5 th day. In an hour after $\mathrm{N}_{2} \mathrm{O}_{4}$ exposure, killing the mice by dislocation to measure the SOD, GSH-Px activity and MDA content in lung tissue, checking pathology change in lung tissue slice. Results were shown: the $1.25,2.50 \mathrm{~g} / \mathrm{kg}$ FP increased SOD (U/mg pro) by $30.3 \%$ and $24.4 \%$, GSH-Px (U/mg pro) by $77.4 \%$ and $60.9 \%$, respectively. Pathological observation of lung tissue showed that three FP groups had lighter damage than the physiological saline $+\mathrm{N}_{2} \mathrm{O}_{4}$ group. So, FP has significant protective effects on damage caused by $\mathrm{N}_{2} \mathrm{O}_{4}$ in mice.
\end{abstract}

\section{INTRODUCTION}

Lotus (Nelumbonucifera Gaertn) is an important member of medicinal aquatic plants. Its leaf is widely applied in Indian or Chinese traditional medicine for treatment on various diseases and alleviation of corresponding symptoms. Because of its good anti-tumor, anti-oxidation, inhibition of liver fibrosis, hypoglycemia $^{[1]}$, anti-inflammatory, antiarrhythmic, antipyretic, immunomodulatory, antibacterial, antiinflammatory, cardiovascular protection, and other activities $^{[2]}$, deep development for lotus leaf is paid attention to, especially, main chemical components polyphenol and flavonoid, as well as polysaccharides, volatile oils and trace elements. $\mathrm{N}_{2} \mathrm{O}_{4}$ is a kind of liquid propellant of large launch rocket used in the United States and other countries ${ }^{[3]}$. It is a strong oxidant, through inhalation which can cause bronchial epithelial damage, reduce the phagocytosis activity of alveolus phagocytes, increase the incidence of chronic infection of respiratory tract significantly, and then cause the chronic inflammation of the respiratory tract $[4,5]$. Flavonoid and polyphenol are important active substances in plants, such as scavenging free radical, detoxification, maintaining DNA biosynthesis, maintaining normal growth and immunity of cell, widely used in biomedical and food processing fields ${ }^{[6]}$. In this paper, the protective effects of flavonoid and polyphenol on lung damage induced by the inhalation of $\mathrm{N}_{2} \mathrm{O}_{4}$ in mice was studied.

\section{MATERIALS AND METHODS}

Preparation of flavonoid and polyphenol from lotus leaf. Fresh lotus leaves were gathered from Hou Guan lake of Wuhan city, and its flavonoid and polyphenol were extracted with ethanol at our laboratory at following conditions: ethanol concentration $40 \%$, ratio of leaf and liquid 1:30, extraction temperature $30^{\circ} \mathrm{C}$, extraction time $120 \mathrm{~s}$. The extraction liquid was concentrated and vacuum freeze dried to collect lotus leaf extraction powder. Flavonoid and polyphenol were determinated by spectrophotometry method (rutin and gallic acids standard ample, Sigma Co.). The flavonoid content was $93.7 \mathrm{mg} / \mathrm{g}$ and polyphenol $11.2 \mathrm{mg} / \mathrm{g}$.

\subsection{Experimental animals}

Healthy male ICR mice, of clean grade, with the body weight of $18-22 \mathrm{~g}$, provided by the Experimental Animal Science Department of Medical College, Beijing University. Experimental animal license number: SYXK (Beijing) 2016-0025. The temperature of animal

\footnotetext{
*Corresponding author: wesleyi@163com and lideyuan66@sina.com
} 
breeding room was maintained at $22 \pm 1{ }^{\circ} \mathrm{C}$, humidity $50 \%$, free feeding and drinking.

\subsection{Instruments and Equipments}

120 L toxicant exposure counter, Special Medical Center of 306 Hospital.

\subsection{Reagents}

Liquid $\mathrm{N}_{2} \mathrm{O}_{4}$ was provided by 101 Institute of Aerospace Industrial Research Academy. Coomassie brilliant blue protein and the assay kits of SOD, GSH-Px, MDA were provided by Nanjing Jiancheng Bioengineering Institute.

\subsection{Construction of animal damage model}

Referring to the method of Mingliang $\mathrm{Ye}^{[7]}$, by the way of inhaling $\mathrm{N}_{2} \mathrm{O}_{4}$ in the toxicant exposure cabinet. Volume of the toxicant exposure cabinet was $120 \mathrm{~L}$. Temperature in the cabinet was maintained at $25 \pm 0.5^{\circ} \mathrm{C}$. Liquid $\mathrm{N}_{2} \mathrm{O}_{4}(45 \mu \mathrm{l})$ was injected by the micro-syringe and vaporized. Start the fan to make the $\mathrm{N}_{2} \mathrm{O}_{4}$ steam distributed uniformly in the cabinet. Expect the mice of normal control group, all mice were exposed to $\mathrm{N}_{2} \mathrm{O}_{4}$ in the toxicant exposure cabinet. Mice breathed freely in the cabinet. Inhalation exposure time was 30 minutes, adding liquid $\mathrm{N}_{2} \mathrm{O}_{4}(1 \mu \mathrm{l})$ to the cabinet every $5 \mathrm{~min}$. After exposure, the mice were removed from the cabinet, feeding and drinking normally.

\subsection{Animals grouping and treatment}

Totally 70 healthy male ICR mice, of clean grade, were randomly divided into 5 groups: normal control group, saline $+\mathrm{N}_{2} \mathrm{O}_{4} \quad$ group, $1.25 \mathrm{~g} / \mathrm{kgFP}+\mathrm{N}_{2} \mathrm{O}_{4}$ group, 2 . $50 \mathrm{~g} / \mathrm{kgFP}+\mathrm{N}_{2} \mathrm{O}_{4}$ group and $3.75 \mathrm{~g} / \mathrm{kg} \mathrm{FP}+\mathrm{N}_{2} \mathrm{O}_{4}$ group, 15 mice in each group except the normal control group $(n=10)$. Adding FP powder into the physiological saline to prepare the solution for oral administration, then the mice in three FP intervention groups were administered with FP by oral administration at the dosage of $1.25,2$. $50,3.75 \mathrm{~g} / \mathrm{kg}$ respectively, $0.4 \mathrm{ml}$ for each mouse, once a day for 5 days. The mice in physiological saline $+\mathrm{N}_{2} \mathrm{O}_{4}$ group were administered with physiological saline by oral gavage, $0.4 \mathrm{ml}$ for each mouse, once a day for 5 days. The exposure was conducted at 1 sth after intragastric administration on the 5th day, mice were killed by dislocation at 12 th hour after the inhalation intoxication of $\mathrm{N}_{2} \mathrm{O}_{4}$, then taking 10 mice from each group to make lung tissue slice and determine the SOD activity, GSHPx activity and MDA content of lung tissue, the other 5 mice were killed to make lung tissue slice on the 7 th day after exposure.

\subsection{Indexes Determination}

Place the lung tissue into the glass tube, add a certain amount of ice saline accurately into the glass tube with micropipette, then homogenize the tissue. Centrifugate the prepared homogenate at $14000 \mathrm{rpm}$, at $4^{\circ} \mathrm{C}$, for $10 \mathrm{~min}$. Take appropriate supernatant to determine SOD activity, GSH-Px activity, MDA content.

\subsection{Pathological examination}

After the mice were killed, their thoracic cavity were opened and general lung pathological changes were observed. The whole lung tissue was soaked in $10 \%$ formalin solution and fixed for a week. Pathological changes were observed under light microscope according to conventional pathology methods of progressively dehydrating, transparence, embedding, sectioning and HE staining.

\subsection{Statistical analysis}

The data of measurement result were expressed with $\bar{x} \pm s$ and carried out t-test statistical analysis with SPSS16. 0 software.

\section{RESULTS AND ANALYSIS}

\subsection{Effect of FP on activities of SOD, GSH-Px and MDA content in lung tissue of mice exposed to $\mathrm{N}_{2} \mathrm{O}_{4}$.}

Compared with the normal control group, SOD activity (42.95 U/mg pro) in saline+ $\mathrm{N}_{2} \mathrm{O}_{4}$ group, showing significant decrease $(\mathrm{P}<0.01)$. Compared with the saline $+\mathrm{N}_{2} \mathrm{O}_{4}$ group, SOD activity $(55.97 \mathrm{U} / \mathrm{mg}$ pro in $1.25 \mathrm{~g} / \mathrm{kgFP}+\mathrm{N}_{2} \mathrm{O}_{4}$ group, $53.44 \mathrm{U} / \mathrm{mg}$ pro in 2 . $50 \mathrm{~g} / \mathrm{kgFP}+\mathrm{N}_{2} \mathrm{O}_{4}$ group) increased by $30.3 \%$ and $24.4 \%$ $(\mathrm{P}<0.01)$ respectively, while $\mathrm{SOD}$ activity $(45.26 \mathrm{U} / \mathrm{mg}$ pro) in $3.75 \mathrm{~g} / \mathrm{kgFP}+\mathrm{N}_{2} \mathrm{O}_{4}$ group showed no difference (Table 1).

Compared with the normal control group, GSH-Px activity (4.17 $\mathrm{U} / \mathrm{mg}$ pro) in saline $+\mathrm{N}_{2} \mathrm{O}_{4}$ group, exhibiting significant decrease, too $(\mathrm{P}<0.01)$. Compared with the saline $+\mathrm{N}_{2} \mathrm{O}_{4}$ group, GSH-Px activity (7.40 $\mathrm{U} / \mathrm{mg}$ pro in $1.25 \mathrm{~g} / \mathrm{kgFP}+\mathrm{N}_{2} \mathrm{O}_{4}$ group, $6.71 \mathrm{U} / \mathrm{mg}$ pro in $2.50 \mathrm{~g} / \mathrm{kgFP}+\mathrm{N}_{2} \mathrm{O}_{4}$ group, $6.52 \mathrm{U} / \mathrm{mg}$ pro in $3.75 \mathrm{~g} / \mathrm{kgFP}+\mathrm{N}_{2} \mathrm{O}_{4}$ group) increased by $77.4 \%, 60.9 \%$, and $56.3 \%(\mathrm{p}<0.01)$ respectively.

MDA content of lung tissue in all $\mathrm{N}_{2} \mathrm{O}_{4}$ exposure groups decreased, Compared with the normal control group. Especially, MDA content $(5.99 \mathrm{mmol} / \mathrm{L})$ in saline $+\mathrm{N}_{2} \mathrm{O}_{4}$ group, showing significant decrease $(\mathrm{P}<0.01)$. Compared with saline $+\mathrm{N}_{2} \mathrm{O}_{4}$ group, MDA content (11. $66 \mathrm{mmol} / \mathrm{L})$ in $1.25 \mathrm{~g} / \mathrm{kg} \mathrm{FP}+\mathrm{N}_{2} \mathrm{O}_{4}$ group increased by $94.6 \%(\mathrm{P}<0.01)$. 
Table 1 Effect of flavonoid and polyphenol on activities of SOD,GSH-Px and MDA content in lung tissue of mice after 12h of exposed to $\mathrm{N}_{2} \mathrm{O}_{4}(\bar{x} \pm S, \mathrm{n}=10)$

\begin{tabular}{|c|c|c|c|}
\hline Groups & $\begin{array}{l}\text { SOD activity } \\
\text { (U/mg pro) }\end{array}$ & $\begin{array}{c}\text { GSH-Px } \\
\text { activity } \\
\text { (U/mg pro) }\end{array}$ & $\begin{array}{c}\text { MDA } \\
\text { content } \\
(\mathrm{mmol} / \mathrm{L})\end{array}$ \\
\hline Normal & $56.84 \pm 3.90$ & $9.74 \pm 1.39$ & $16.47 \pm 2.97$ \\
\hline saline $+\mathrm{N}_{2} \mathrm{O}_{4}$ & $42.95 \pm 2.10^{* *}$ & $4.17 \pm 0.26^{* *}$ & $5.99 \pm 0.54^{* *}$ \\
\hline $\begin{array}{l}1.25 \mathrm{~g} / \mathrm{kg} \\
\mathrm{FP}+\mathrm{N}_{2} \mathrm{O}_{4}\end{array}$ & $55.97 \pm 2.72^{\triangle \Delta}$ & 7. $40 \pm 0.95^{\triangle \Delta}$ & $11.66 \pm 1.75^{\triangle \Delta}$ \\
\hline $\begin{array}{l}\text { 2. } 50 \mathrm{~g} / \mathrm{kg} \\
\mathrm{FP}+\mathrm{N}_{2} \mathrm{O}_{4}\end{array}$ & 53. $44 \pm 1.80^{\triangle \Delta}$ & $6.71 \pm 0.63^{\triangle \Delta}$ & $9.80 \pm 1.57^{\triangle}$ \\
\hline $\begin{array}{l}3.75 \mathrm{~g} / \mathrm{kg} \\
\mathrm{FP}+\mathrm{N}_{2} \mathrm{O}_{4}\end{array}$ & $45.26 \pm 2.02$ & $6.52 \pm 0.56^{\triangle \Delta}$ & $10.37 \pm 1.53^{\triangle}$ \\
\hline
\end{tabular}

**: $\mathrm{P}<0.01$ vs normal group; $\triangle: \mathrm{P}<0.05, \triangle \triangle: \mathrm{P}<0.01$ vs $\mathrm{N}_{2} \mathrm{O}_{4}$ group

\section{2 Effects of FP on the lung tissue pathological changes in mice exposed to $\mathrm{N}_{2} \mathrm{O}_{4}$.}

Taking the $1.25 \mathrm{~g} / \mathrm{kgFP}+\mathrm{N}_{2} \mathrm{O}_{4}$ group to observe the lung tissue pathological changes. Compared with the normal control group, the mice in saline $+\mathrm{N}_{2} \mathrm{O}_{4}$ group showed significant pathological changes in the lung tissue, pulmonary alveolus structure was damaged, the number of pulmonary alveolus was reduced, pulmonary alveolus size was unequal, alveolus interstitium was widened, matrix was increased significantly, mononuclear cell infiltration occurred, some tissue was fiberized and showed cord-like distribution. Dilatation and congestion of small veins within the lung tissue and capillary within pulmonary alveolus wall were observed, pink serous fluid was exuded, part of the pulmonary alveolus wall was destructed into small cysts. $12 \mathrm{~h}$ after inhalation of $\mathrm{N}_{2} \mathrm{O}_{4}$ lung tissue was swelled and the volume was increased. Lung tissue swelling and turning white, mixed with some substantial lesion areas were observed in saline $+\mathrm{N}_{2} \mathrm{O}_{4}$ group on 7 th day after exposed to $\mathrm{N}_{2} \mathrm{O}_{4}$. Compared with the saline $+\mathrm{N}_{2} \mathrm{O}_{4}$ group, the severity of pathological lesions in $\mathrm{FP}+\mathrm{N}_{2} \mathrm{O}_{4}$ group was obviously relieved, pathological examination showed that the severity of pulmonary alveolus structure damage, the decline of the number of pulmonary alveolus, the severity of mononuclear cell infiltration and lung tissue fibrosis were eased significantly (Figure 1). $1.25 \mathrm{~g} / \mathrm{kg} \mathrm{FP}$ has significantly protective effects on lung injury induced by the inhalation of $\mathrm{N}_{2} \mathrm{O}_{4}$ in mice.

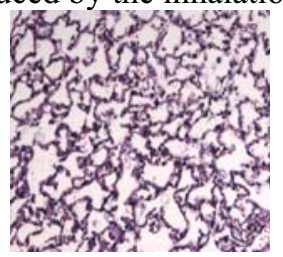

a. Lung tissue in normal control mice $(\mathrm{HE}, \times 100)$

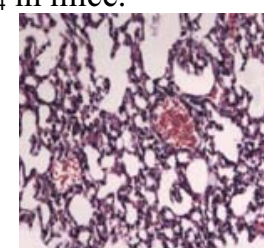

b. Pulmonary hemorrhage, edema and inflammatory cell infiltration in lung tissue in physiological saline $+\mathrm{N}_{2} \mathrm{O}_{4}$ group at 12 th hour after injury $(\mathrm{HE}, \times 100)$

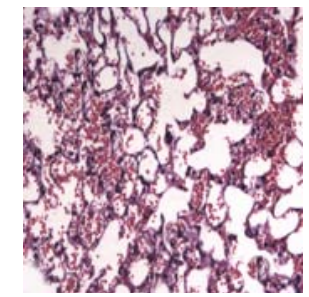

c. Pulmonary hemorrhage, edema and inflammatory cell infiltration in lung tissue in physiological saline $+\mathrm{N}_{2} \mathrm{O}_{4}$ group at 7 th day after injury (HE, $X$ 100)

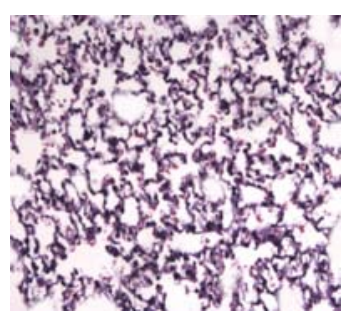

d. Pulmonary hemorrhage, edema and inflammatory cell infiltration in lung tissue in $\mathrm{FP}+\mathrm{N}_{2} \mathrm{O}_{4}$ group at 12 th $\mathrm{h}$ after injury $(\mathrm{HE}, \times 100)$

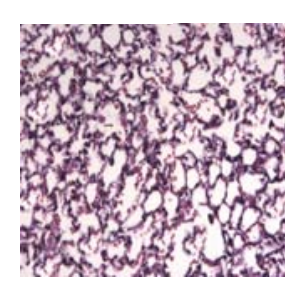

e. Pulmonary hemorrhage, edema and inflammatory cell infiltration in lung tissue in $\mathrm{FP}+\mathrm{N}_{2} \mathrm{O}_{4}$ group on 7 th day after injury $(\mathrm{HE}, \times 100)$

Figure 1. Lung tissue of mice was sectioned and enlarged by $\mathrm{HE}$

\section{DISCUSSION}

\subsection{N2O4 injury mechanism analysis.}

$\mathrm{N}_{2} \mathrm{O}_{4}$ has strong oxidizing capacity, unstable, and easily decomposed into $\mathrm{NO}_{2}$ at room temperature. The main target organ of $\mathrm{NO}_{2}$ damage is lung. $\mathrm{NO}_{2}$ can cause a variety of injury of bronchial epithelial cells and alveolus epithelial cells, its mechanism of action is related to free radicals and peroxidation damage [4]. Oxidative and peroxidation damage and function change of antioxidant system can lead to the changes of lipid peroxidation products MDA content, such as increase of MDA content, the decrease of SOD and FP-Px, catalase (CAT) activities and so on.

FP is widely present in plant tissues. This study showes that flavonoid and polyphenol at low dosage can significantly increase activities of SOD, GSH-Px in the lung tissue of mice. Mechanism of the protective effects of flavonoid and polyphenol on acute lung damage induced by the inhalation of $\mathrm{N}_{2} \mathrm{O}_{4}$ in mice is attributed to their reduction capacity: FP is small molecule antioxidants, which can directly react with $\mathrm{N}_{2} \mathrm{O}_{4}$ inhaled into lung and reduce its harm. In this study, the mice with lung damage induced by inhalation of $\mathrm{N}_{2} \mathrm{O}_{4}$ were given high doses of FP $(3.75 \mathrm{~g} / \mathrm{kg})$, the lung tissue SOD activity was not significantly higher than the normal control group, its detailed mechanism needed further study.

The study showed that after exposed to $\mathrm{N}_{2} \mathrm{O}_{4}$, lung tissue MDA content in the mice of all $\mathrm{N}_{2} \mathrm{O}_{4}$ poisoning group significantly declined. This is obviously different from general oxide. Under normal circumstances, oxides can decrease activities of SOD and GSH-Px in blood or tissue, at the same time, increase MDA content. 
However, our study showed that $\mathrm{N}_{2} \mathrm{O}_{4}$ poisoning could decrease the activities of SOD, GSH-Px and MDA content in tissue of mice simultaneously. Its mechanism may be correlated with $\mathrm{N}_{2} \mathrm{O}_{4}$ (NO2) promoting conversion and elimination of MDA, through changing metabolic pathways of lipid peroxidation and forming other products [8], resulting in lung tissue MDA content showing a certain downward trend.

FP widely existes in plants, for example, lotus leaf, grapes, sweet potatoes. Personnel engaged in production and storage of special rocket fuel $\mathrm{N}_{2} \mathrm{O}_{4}$, taking more foods such as yeast, lotus leaf, grapes, and sweet potatoes for their daily recipe, is wise. Lotus leaf, as basic materials, utilized to develop special functional food against $\mathrm{N}_{2} \mathrm{O}_{4}$ damage will exhibit good prospect.

\section{CONCLUSION}

$\mathrm{N}_{2} \mathrm{O}_{4}$ resulted in SOD, GSH-Px and MDA levels decreasing in mouse lung tissue. This study presented that FP has significant protective effects on damage caused by $\mathrm{N}_{2} \mathrm{O}_{4}$ in mice. FP were a promising approach to developing functional food against $\mathrm{N}_{2} \mathrm{O}_{4}$ poisoning.

\section{ACKNOWLEDGMENT}

The foundation for Natural Science Foundation of China (grant number 31901643). the foundation for Doctoral startup project of Hubei University of Technology (grant number BSQ2015014), and the foundation for National Innovation and Entrepreneurship Center for College Students (CSIE) of Hubei Province in 2020(grant number S202010500085).

\section{DISCLOSURE}

The authors report no conflicts of interest with this work.

\section{REFERENCES}

1. Eisuke, K., Yosuke, I. and Jun, K. Higenamine 4'$\mathrm{O}-\beta$-d-glucoside in the Lotus Plumule Induces Glucose Uptake of L6 Cells through $\beta$ 2-Adrenergic Receptor. Bioorganic \& Medicinal Chemistry, 2015.

2. Ning Qin, Qing Min, Wenxiang Hu. Review on the Chemical Constituents and Bioactivities of Nelumbinis plumula. Journal of Microwave Chemistry, 2018

3. Butt, Y., A. Kurdowska, and T. C. Allen. Acute lung injury: a clinical and molecular review. Archives of Pathology \& Laboratory Medicine, 2016.

4. Blondonnet, R., J. M. Constantin, V. Sapin, and M. Jabaudon. A pathophysiologic approach to biomarkers in acute respiratory distress syndrome. Disease Markers 2016.

5. Yehya, N, N.J.Thomas. 2016. Relevant outcomes in pediatric acute respiratory distress syndrome studies. Frontiers in Pediatrics. 2015.
6. Papazian, L., C. S. Calfee, D. Chiumello, C. E. Luyt, N. J. Meyer, H. Sekiguchi, M. A. Matthay, and G. U. Meduri.Diagnostic workup for ARDS patients. Intensive Care Medicine 2016.

7. Lee KY. Pneumonia, acute respiratory distress syndrome, and early immune-modulator therapy. International Journal of Molecular Sciences 18.

8. Chen, H., C. Bai, and X. Wang. 2010. The value of the lipopolysaccharide-induced acute lung injury model in respiratory medicine. Expert Review of Respiratory Medicine. 2017. 